\title{
Do Hydro-Retainer Polymers Attenuate Damage from Water Fluctuations in Leaf Metabolism and the Quality of Cedrela odorata Seedlings?
}

\author{
Márcio Santos da Silva ${ }^{\dagger}$, Silvana P. Q. Scalon ${ }^{*}$, Juliana Milene Silverio ${ }^{\dagger}$, Joice K.V. Santos ${ }^{\dagger}$, Cleberton Correia Santos $^{\dagger}$ \\ and Daiane Mugnol Dresch ${ }^{\dagger}$ \\ Federal University of Grande Dourados, Faculty of Agricultural Sciences, Highway Dourados, Itahum/ km 12, Dourados, \\ 79804-970, Mato Grosso do Sul, Brazil \\ *For correspondence: silvanascalon@ufgd.edu.br \\ †Contributed equally to this work and are co-first authors
}

Received 26 September 2020; Accepted 30 December 2020; Published 10 July 2021

\begin{abstract}
Water stress, caused by excess or lower of water, can negatively affect leaf metabolism and seedling growth and prevent it from developing its maximum genetic potential. In this sense, it is necessary to use as that can mitigate these deleterious effects on plants at their initial phase of growth. The aim of this work was to evaluate the effect of hydrogel in the mitigation of water stress (deficit and flooding) on photosynthetic metabolism and growth characteristics of $C$. odorata seedlings, and also evaluate their recovery potential after the resumption of irrigation. The characteristics of photosynthetic metabolism, growth and quality of $C$. odorata seedlings showed a reduction caused by water fluctuations, indicating sensitivity to these conditions, although photosynthesis photochemistry was affected to a lower extent. The addition of the hydro-retainer polymer contributed little to the biochemical and photochemical indicators of photosynthesis and seedling quality, a fact that directs us to reject our hypothesis that its use promotes mitigation of damage to the photosynthetic apparatus and to the growth. Cedrela odorata is sensitive to water variations in the soil, but recovers the photosynthetic metabolism and quality of the seedlings once the stressful water condition is suspended. The application of the hydro-retainer polymer mitigated, but the seedlings recovered regardless of their presence. (C) 2021 Friends Science Publishers
\end{abstract}

Keywords: Chlorophyll $a$ fluorescence; Flooding; Water deficit; Recovery; Gas exchanges

\section{Introduction}

Among the abiotic factors that influence the growth, development and establishment of seedlings, water stress plays a prominent role. Lack or excess of water can be a limiting factor that prevents the plant from developing to the maximum of its genetic potential. Stress can also generate accumulation of carbohydrates (protein stabilization) causing a decrease in cell volume, making cell content more viscous, increasing the chance of molecular interactions that can cause protein denaturation and membrane fusion (Bianchi et al. 2016), there is also an increase in reactive oxygen species - ROS (Miller et al. 2010). Under adverse conditions, some species present stomatal closure and leaf drop due to the increase of abscisic acid (Taiz et al. 2017).

The exposure of a particular species to extreme conditions can demonstrate whether it has the capacity to adapt itself and tolerate the limiting environment in which it is growing. In addition to the many possibilities that the plant demonstrates to overcome the water deficit, technologies have been used to mitigate these damages thereby allowing plants to grow and develop even under water deficit situations.

Among the technologies currently available, there are the hydro-retainer polymers, which have the capacity to retain water and make it available slowly according to the needs of the plant (Navroski et al. 2016). Hydro-retainer polymers, also known as hydrogel, hydro absorbent polymer and super absorbent polymer, have some recognized effects since the beginning of their use, such as increased soil water retention, reduced nutrient leaching, improvement in cation exchange capacity and greater water availability for plants (Azevedo et al. 2002).

As a consequence of the exploitation of natural resources carried out by humankind, the maintenance of forest diversity has been massively debated, and it is necessary to obtain information on the dynamics of the species that make up this environment. Cedrela odorata L. (Meliaceae), also known as cedar, pink cedar, brown cedar, red cedar, has the Amazon as its center of origin, but its

To cite this paper: Santos da Silva M, SPQ Scalon, JM Silverio, JKV Santos, CC Santos, DM Dresch (2021). Do hydro-retainer polymers attenuate damage from water fluctuations in leaf metabolism and the quality of Cedrela odorata seedlings? Intl J Agric Biol 26:209-216 
occurrence extends to the State of Santa Catarina. This species has high commercial added value, being exploited because its wood is highly valuable, both in national and international markets (Vieira et al. 2018). The cedar tree also has the potential to be used in forest enrichment plantations, which are usually carried out in open ranges in the forest, using seedlings of fast-growing species and high commercial value (Vieira et al. 2018).

According to its ecology, $C$. odorata it is a deciduous, heliophyte plant, originated from deep, clayey, well drained and moist soils of dry lands (Lorenzi 2013). Also considered a pioneer species, it can be used for restoration of degraded areas and also medicinal purposes (Kew 2015). This plant is dynamic because it contributes both economically and ecologically to the environment in which it is growing. We hypothesized in this research that the use of hydro-retainer polymers mitigates the effects of water fluctuation, represented by water deficit followed by flooding by stabilizing gas exchange, chlorophyll a fluorescence and growth of $C$. odorata seedlings, enabling their survival and recovery once the water availability is restored to regular levels. In this context, the aimed of this work was to evaluate the effect of hydrogel on the mitigation of water stress on photosynthetic metabolism and growth characteristics of $C$. odorata seedlings and their recovery potential after the resumption of irrigation.

\section{Materials and Methods}

\section{Experimental details and treatments}

Experimental material: The experiment was carried out from September to November 2019, at the Faculty of Agricultural Sciences of the Federal University of Grande Dourados (UFGD), in Dourados - Mato Grosso do Sul (MS), Brazil, in a nursery with $30 \%$ shading, achieved with black nylon fabric known as Sombrite ${ }^{\circledR}$ and additional plastic, to protect against precipitation.

The ripe fruits of $C$. odorata were collected in the Cerrado area, in the region of the Itamarati settlement $\left(22^{\circ}\right.$ 11' 24.731" S 55 35' 37.370" E), Ponta Porã, MS. The fruits were manually processed, and the seeds extracted were sown in tubes of $270 \mathrm{~cm}^{3}$ filled with commercial substrate Bioplant $^{\circledR}$ and sand $(1: 1, \mathrm{v} / \mathrm{v})$. At 40 days after sowing, the seedlings were transferred to $8 \mathrm{~L}$ plastic vessels, filled with Bioplant $^{\circledR}$, coarse sand and Dystrophic Red Latosol (1:1:1, $\mathrm{v} / \mathrm{v})$, with daily irrigations of $70 \%$ of the water retention capacity for 30 days, characterizing the acclimatization period. The experiment began with 70 days old seedlings.

Treatments: The seedlings were separated into three groups based on the following water regimes: R1) Continuous irrigation - I, in which $75 \%$ of water retention capacity (WRC) was maintained through the gravimetric method (Souza et al. 2000), R2). Intermittent water stress II, simulated by water fluctuations of deficit and flooding and R3) Intermittent water stress associated with the hydro- retainer polymer $-\mathrm{II}+\mathrm{H}$ added in the seedling pits in gel form during the transplant of the seedlings. Fifty $\mathrm{mL}$ of polymer was added in the hydrator form inside each pit, which in turn contained two seedlings each. The hydrogel dosage used was $4 \mathrm{~g} \mathrm{~L}^{-1}$. The hydrogel used was Forth Gel for Planting, being harmless to the environment and odorless, with the appearance of white micro-crystals. It is a Polyacrylic Copolymer of Potassium Polyacrylamide, with cationic exchange capacity: $532.2600\left(\mathrm{mmol}_{\mathrm{c}} / \mathrm{dm}^{3}\right)$ and WRC: $1.526 .6900 \%$.

Initially, the plants were evaluated at time zero (T0 beginning of the experiment), right before the irrigation was suspended. Soon after, the experiment was carried out in two phases of stress; the first with the suspension of the irrigation until the photosynthetic rate $(A)$ of one of the stress treatments presented values close to zero $\left(1^{\text {st }} \mathrm{P} 0\right)$, and second the irrigation was resumed until the values of $A$ were close to that of the control seedlings under continuous irrigation $\left(1^{\text {st }}\right.$ REC $)$.

Subsequently, the seedlings were submitted to second phase of the stress cycle, characterized by flooding, in which plants were stored in pools with water depth $\sim 5.0 \mathrm{~cm}$ above the substrate level, being monitored until the photosynthetic rate reduced to values close to zero $\left(2^{\text {nd }} \mathrm{P} 0\right)$. Then, the seedlings were taken out of the pool and were left to drain for 15 days. After that irrigation was resumed until the values of the photosynthetic rate were similar to that of the control seedlings ( $2^{\text {nd }}$ REC).

The treatments were arranged in a completely randomized design, in a subplots scheme, and three water regimes were allocated in plots, five evaluation periods in the subplots, with three replications, with two plants per pot in each experimental unit.

\section{Plant harvesting and measurements}

Gas exchange: photosynthetic rate $(A)$, stomatal conductance $\left(g_{\mathrm{s}}\right)$ and internal $\mathrm{CO}_{2}$ concentration $\left(C_{\mathrm{i}}\right)$ were quantified using the infrared gas analyzer (IRGA; ADC, LCi PRO; Analytical Development Co. Ltd, Hoddesdon, $\mathrm{UK})$. From these data, Rubisco carboxylation $\left(A / C_{i}\right)$ was calculated. The evaluations were made between 8 and $11 \mathrm{~h}$, selecting four seedlings, previously chosen and marked.

Chlorophyll- $\boldsymbol{a}$ fluorescence: the potential quantum efficiency of photosystem II $\left(\mathrm{F}_{\mathrm{V}} / \mathrm{F}_{\mathrm{M}}\right)$, absorbed energy conversion efficiency $\left(\mathrm{F}_{\mathrm{V}} / \mathrm{F}_{0}\right)$ and basal quantum production of non-photochemical processes $\left(\mathrm{F}_{0} / \mathrm{F}_{\mathrm{M}}\right)$ were obtained from chlorophyll fluorescence data measured with the aid of the portable fluorometer OS-30p (Opti-Sciences Chlorophyll Fluorometer, Hudson, USA). The fluorescence results were obtained between 8 and 11 o'clock in the morning, in the same plants used to evaluate the gas exchange, that were then submitted to dark conditions for 25 min using clips, so that all reaction centers in that leaf region acquired the "open configuration", indicating the complete oxidation of the photosynthetic electron transport system. 
Chlorophyll index: This was measured using the Soil Plant Analysis Development chlorophyll meter (SPAD-502, Konica-Minolta, Tokyo, Japan). The readings were executed in the morning, using fully expanded leaves located in the middle third.

Relative water content (RWC): The RWC was measured following Slavick (1979) method using the weights of fresh, saturated and dried masses of three leaf discs per plant.

Growth: The leaf area was determined with leaf area integrator LI-COR ${ }^{\circledR}$ (LI 3100, Nebraska, USA). To evaluate the quality of the seedlings, the height, diameter and dry biomass data of aerial parts and roots were used and the Dickson quality index - DQI (Dickson et al. 1960) was calculated.

\section{Statistical analysis}

The data were submitted to variance analysis (ANOVA) and when significant ( $F$ test, $p<0.05$ ), the means as a function of water conditions, the evaluation periods and the interactions were submitted to the Tukey test $(p<0.05)$, using the statistical program SISVAR 5.3 (Ferreira 2014).

\section{Results}

After 14 days of water restriction, the photosynthetic rate (A) values reached 0.32 and $0.45 \mu \mathrm{mol} \mathrm{m} \mathrm{m}^{-2} \mathrm{~s}^{-1}$ in plants cultivated under water deficit $\left(1^{\text {st }} \mathrm{P} 0\right)$ without and with hydrogel, respectively. The values did not vary significantly from each other, demonstrating that the hydro-retainer polymer did not contribute to the mitigation of stress due to water deficit and to maintenance of $A$ in this period (Fig. 1a). However, 12 days after flooding the seedlings without $\mathrm{H}$ showed a significant decrease of $A\left(0.54 \mu \mathrm{mol} \mathrm{m} \mathrm{m}^{-2} \mathrm{~s}^{-1}\right)$ $\left(2^{\text {nd }} \mathrm{P} 0\right)$ and we emphasize that $\mathrm{H}$ maintained slightly higher $A$ values (3.06 $\mu \mathrm{mol} \mathrm{m} \mathrm{m}^{-2} \mathrm{~s}^{-1}$ ) (Fig. 1a), demonstrating the beneficial effect of $\mathrm{H}$ in this period.

Similarly to the response of $A$, we found a decline in gs during water fluctuations, i.e., in the $1^{\text {st }}$ and $2^{\text {nd }} \mathrm{P} 0$, in both plants with and without $\mathrm{H}$, with values of 0.01 and $0.03\left(1^{\text {st }} \mathrm{P} 0\right)$ and 0.02 and $0.03 \mathrm{~mol} \mathrm{~m}^{-2} \mathrm{~s}^{-1}\left(2^{\text {nd }} \mathrm{P} 0\right)$. Once the irrigation was resumed, as for the plants previously under stress, although they increased in $g s$, in the $1^{\text {st }}$ REC they maintained lower values than the control plants. In the $2^{\text {nd }}$ REC the $g_{\text {s }}$ did not differ statistically between treatments (Fig. 1b). We observed significant increases in $C_{\mathrm{i}}$ in the $1^{\text {st }}$ and $2^{\text {nd }} \mathrm{P} 0$, in plants without $\mathrm{H}$, with values of 328.66 and $373.66 \mu \mathrm{mol} \mathrm{m} \mathrm{m}^{-1}$, respectively. Plants cultivated with $\mathrm{H}$ maintained their low values (222.00 and $286.66 \mu \mathrm{mol} \mathrm{m} \mathrm{m}^{-1}$ ) and did not differ statistically from those irrigated daily (Fig. 1c).

However, even with lower $C_{\mathrm{i}}$ in the $1^{\text {st }} \mathrm{P} 0$, plants with $\mathrm{H}$ presented lower Rubisco carboxylation efficiency, but in $2^{\text {nd }} \mathrm{P} 0$, these same plants presented higher $A / C_{\mathrm{i}}$ value. In general, in the two recovery phases, the seedlings presented resumption of photosynthetic metabolism, where in the $2^{\text {nd }}$
REC the seedlings with $\mathrm{H}$ reached values higher than the other treatments.

When using $H$, the $F_{V} / F_{M}$ value in seedlings submitted to water deficit $\left(1^{\text {st }} \mathrm{P} 0\right)$ was higher (mean of 0.685$)$ than those observed in seedlings without $\mathrm{H}(0.643)$, however, photochemical efficiency was negatively affected by the water deficit condition. These values are below the critical limit of 0.750 , considered a reference for non-stressed plants, thus showing that $\mathrm{H}$ contributed little to the maintenance of photochemical activity during this period (Fig. 2a). In the $1^{\text {st }}$ REC after the irrigation was resumed, the previously stressed plants increased their quantum fluorescence value, but could not recover the values and match those of the control seedlings. However, in the $2^{\text {nd }}$ REC the seedlings recovered regardless of the presence of $H$. presenting means higher than 0.750 which did not differ from the irrigated control. Thus, we emphasize that the $\mathrm{F}_{\mathrm{V}} / \mathrm{F}_{\mathrm{M}}$ responded more pronouncedly to the presence of $\mathrm{H}$ in the soil than the other photochemical indicators.

Plants cultivated with $\mathrm{H}$, in the two times of water stress, presented $\mathrm{F}_{\mathrm{V}} / \mathrm{F}_{0}$ values similar to those without $\mathrm{H}$ and lower than those of plants under continuous irrigation. During the $1^{\text {st }} \mathrm{REC}, \mathrm{H}$ contributed positively to the recovery and increase of $\mathrm{F}_{\mathrm{V}} / \mathrm{F}_{0}$ with an average of 3.6, not differing statistically from the control. Once the flooding was suspended, in the $2^{\text {nd }}$ REC, the previously stressed treatments differed statistically from the control, however their light absorption efficiency increased in photosystems II, where plants with and without $\mathrm{H}$ presented final values of 5.23 and 4.76, respectively (Fig. 1b).

The $\mathrm{F}_{0} / \mathrm{F}_{\mathrm{M}}$ was higher in seedlings without $\mathrm{H}$ in the two stress times, however it was less pronounced in the $2^{\text {nd }} \mathrm{P} 0$ (Fig. 2c). The presence of $\mathrm{H}$ had no significant effect for the recovery of this characteristic that did not vary among plants in the REC phases, when the values were similar to that of the control seedlings. The sharp increase of this characteristic mainly of $1^{\text {st }} \mathrm{P} 0$ indicates a stress condition; therefore it is harmful to photochemical processes. The chlorophyll index remained lower at the two stress periods although in the $1^{\text {st }}$ $\mathrm{P} 0$ the presence of $\mathrm{H}$ mitigated this effect, which did not occur in the $2^{\text {nd }} \mathrm{P} 0$. We emphasize that the SPAD index recovered regardless of the presence of $\mathrm{H}$ (Fig. $2 \mathrm{~d}$ ).

The smallest leaf areas occurred in the seedlings cultivated in the two phases of water stress $\left(1^{\text {st }}\right.$ and $\left.2^{\text {nd }} \mathrm{P} 0\right)$ regardless of the presence of $\mathrm{H}$, with values of 32.6 and $344.4 \mathrm{~cm}^{2}$, respectively, as well as in the two recoveries, emphasizing that in the $1^{\text {st }}$ REC the seedlings without $H$ the leaf area was significantly lower (Fig. 3a). Thus, $\mathrm{H}$ did not favor the complete leaf area recovery of previously stressed seedlings, which remained smaller than the leaf area of the control plants.

We found that the relative water content in the leaves of $C$. odorata seedlings was lower in the deficit and flooding phase, especially in those cultivated without $\mathrm{H}$, compared to the values of seedlings under intermittent water deficit with $\mathrm{H}$ and those continuously irrigated (Fig. 3b). 

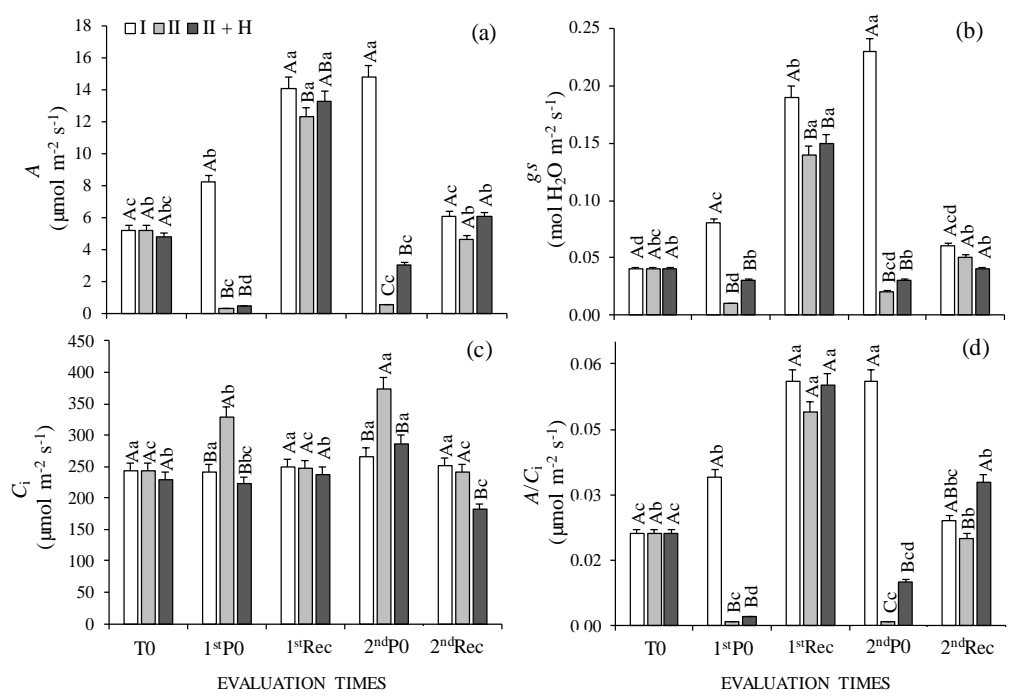

Fig. 1: Photosynthetic rate - $A$ (a), stomatal conductance - $g_{\mathrm{s}}$ (b) intracellular $\mathrm{CO}_{2}$ concentration - $C_{\mathrm{i}}$ (c) RUBISCO carboxylation intrinsic efficiency $-A / C_{\mathrm{i}}(\mathrm{d})$ in seedlings of $C$. odorata in different evaluation times, submitted to water stress (deficit and flooding) and hydrogel

*Capital Letters compare hydric regimes within each evaluation period Lowercase letters compare evaluation periods within each hydric regime
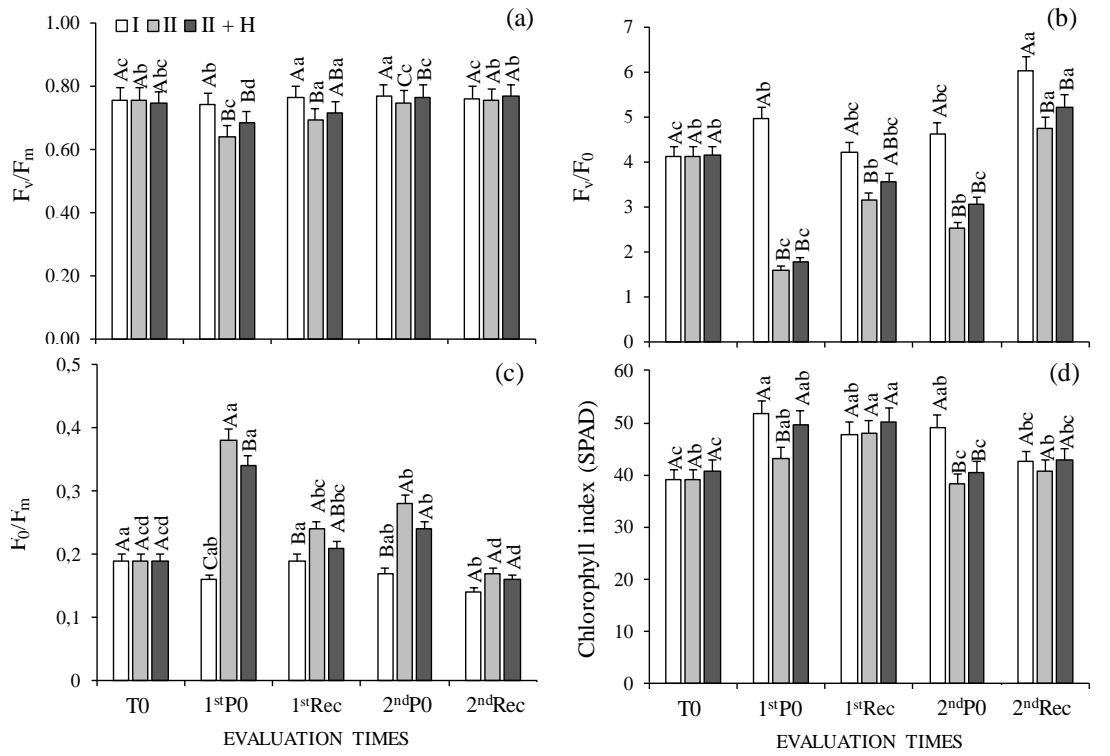

Fig. 2: Potential quantum efficiency of photosystem II - $F_{V} / F_{M}(A)$, absorbed energy conversion efficiency - $F_{V} / F_{0}(B)$ basal quantum production of non-photochemical processes $-\mathrm{F}_{0} / \mathrm{F}_{\mathrm{M}}(\mathrm{C})$, and SPAD chlorophyll index (D) in seedlings of C. odorata in different evaluation times, submitted to water stress (deficit and flooding) and hydrogel

*Capital Letters compare hydric regimes within each evaluation period Lowercase letters compare evaluation periods within each hydric regime

When the irrigation was resumed, there was an increase in the RWC and the presence of $\mathrm{H}$ had little effect for recovery, since the seedlings remained with values slightly higher than those without $\mathrm{H}$; however, both values lower than those of the control, demonstrating that there was no total recovery of water use efficiency. In the $2^{\text {nd }}$ REC, plants with $H$ presented higher value than plants without $H$.

Dickson quality index (DQI) was lower in stressed seedlings, regardless of the presence of $\mathrm{H}$ in both the $1^{\text {st }} \mathrm{P} 0$ and the $1^{\text {st }}$ REC, although it did not vary significant in the $2^{\text {nd }} \mathrm{P0}$ and $2^{\text {nd }}$ REC. In previously stressed plants the Dickson quality index (DQI) was $1.66 \%$ lower than that of the control in the $2^{\text {nd }} \mathrm{P} 0$ regardless of the presence of $\mathrm{H}$ and $2.23 \%$ lower than that of the control seedlings in the $2^{\text {nd }}$ REC without $\mathrm{H}$ and $4.56 \%$ with $\mathrm{H}$, as shown in (Fig. 3c). We emphasize that the DQI was more impaired in the $1^{\text {st }} \mathrm{P} 0$, due to water deficit, when compared to the $2^{\text {nd }} \mathrm{P} 0$, caused by flooding. 

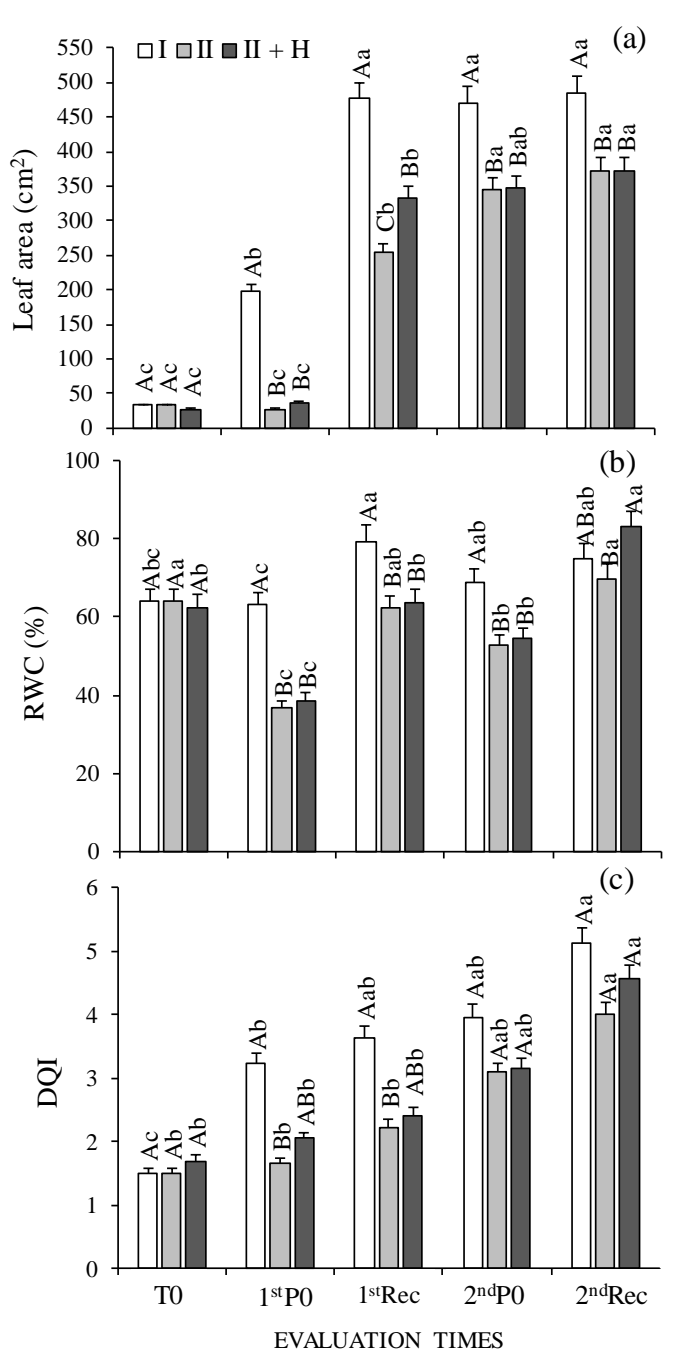

Fig 3: Leaf area (a), relative water content of leaves - RWC (b) and Dickson quality index - DQI (c) in C. odorata seedlings in different evaluation times, submitted to water stress (deficit and flooding) and hydrogel

*Capital Letters compare hydric regimes within each evaluation period Lowercase letters compare evaluation periods within each hydric regime

\section{Discussion}

Although photosynthesis photochemistry was affected to a lower extent, the characteristics of photosynthetic metabolism, growth and quality of $C$. odorata seedlings presented a reduction in function of water fluctuations, indicating sensitivity to these stress conditions. The addition of the hydro-retainer polymer $(\mathrm{H})$ contributed little to the biochemical and photochemical indicators of photosynthesis and to the quality of seedlings, a fact that directs us to reject our hypothesis that its use promotes mitigation of damage to the photosynthetic apparatus and to the growth, although it leads us to question the efficiency of the dose used.

The seedlings with and without $\mathrm{H}$ showed reduction of the RWC in the leaves when submitted to periods of water fluctuations, causing the plants to present lower turgidity. However, $\mathrm{H}$ showed a beneficial effect for this characteristic in the $2^{\text {nd }}$ REC after the flooding condition was suspended. The plants were able to recover, and resume and even reestablish their metabolic and physiological processes resumed and even reestablished. These results suggested that the hydro absorbent polymer, after being added to the soil may take some time to release absorbed water, thus contributing significantly to the development and maintenance of plant turgidity after several critical periods (Bai et al. 2013). These results indicated that C. odorata can return to normal growth conditions, but with the presence of hydrogel the recovery of some characteristics became more significant.

Our results in the phase of water deficit and subsequent flooding for photosynthetic metabolism in seedlings that received $\mathrm{H}$ were not the ones expected when compared to those found in the literature. We considered that the amount of $\mathrm{H}$ hydrated added to the soil at the time of transplanting the seedlings $(50 \mathrm{~mL})$ may have been insufficient since in the previous studies used higher amounts per vessel $(200$ and $250 \mathrm{~mL}$ ) of the hydrogels hydrated (Navroski et al. 2014; Felippe et al. 2016). These doses contributed to promote the beneficial effects of $\mathrm{H}$ in seedlings of different tree species.

In general, even in a small proportion, the highest values of $A, A / C_{\mathrm{i}}$ and lower values of $C_{\mathrm{i}}$ in seedlings with $\mathrm{H}$ in the two periods of water fluctuations and/or recovery, demonstrate their potential mitigating effect, although it did not guarantee the maintenance of leaf area and chlorophyll content and also no improvements in the quality of seedlings evaluated by the DQI.

Thus, we suggest that further studies should be carried out testing higher doses of $\mathrm{H}$ per plant to evaluate the efficiency of this technology in $C$. odorata. Similarly, Ferreira et al. (2014) using 2 L per plant of $\mathrm{H}$ hydrated also found that it did not improve the physiological characteristics of two young citrus cultivars under water deficit. Thus these results allow us to infer that both cultivars "Clemenules" and "Okitsu" are very sensitive to water status variations.

In cultivars sensitive to water fluctuations, the polymer may not have an effect on the growth and maintenance of photosynthesis. We emphasize that the reduction of the values of $A, A / C_{\mathrm{i}}, g s$ and $C_{i}$ elevation observed in this research under water stress (deficit or flooding), are usually found in the literature (Mielke and Schaffer 2010a; 2010b; Junglos et al. 2018; Liang et al. 2019) and it leads to an increase of respiration and production of reactive oxygen species and a change of the functional integrity of chloroplasts and mitochondrial membranes, which affects electron transport through membranes, as observed in the chlorophyll $a$ fluorescence responses of $C$. odorata (Pereira et al. 2012; Vítolo et al. 2012; Bento et al. 2016; Junglos et al. 2018).

It is worth noting that the reduction of $g s$ indicates a mechanism for regulating the transpiration rate, but that 
may compromise $\mathrm{CO}_{2}$ assimilation (Oliveira et al. 2016; Liang et al. 2019). This can be found in high internal concentration (Parolin and Wittmann 2010), as observed for $C_{i}$ in $C$. odorata seedlings, and may demonstrate high sensitivity to water stress. However, $\mathrm{H}$ contributed to the attenuation of the internal $\mathrm{CO}_{2}$ concentration $\left(C_{i}\right)$ during $1^{\text {st }}$ and $2^{\text {nd }} \mathrm{P} 0$ and to the damage to photosynthetic metabolism in $2^{\text {nd }} \mathrm{P} 0$, due to the attenuation of the metabolic reduction of the plant, when the value of $A$ was above the rate of photosynthesis zero $\left(3.06 \mu \mathrm{mol} \mathrm{m} \mathrm{m}^{-2}\right)$. The same did not occur for seedlings with no $\mathrm{H}$, which at 12 days of flooding the values were close to zero. This emphasized that the control seedlings maintained high values of $A(14.08 \mu \mathrm{mol}$ $\left.\mathrm{m}^{-2} \mathrm{~s}^{-1}\right)$.

The contribution of $\mathrm{H}$ in flooding can be attributed to the fact that it is used directly in the root system, and reduces soil density and resistance to penetration, while increasing soil aggregation, porosity and hydraulic conductivity (Agaba et al. 2010; Li et al. 2014; Xu et al. 2015). This in turn enables physiological processes while keeping the photosynthetic apparatus stable for longer periods. The hydrogel ability to retain and provide water more slowly may favor recovery, that is, the ability of seedlings to return to a state of equilibrium after being exposed to stress conditions (Agaba et al. 2011).

We found that the presence of hydrogel did not mitigate the water stress of the seedlings evaluated by photochemical characteristics, except for $\mathrm{F}_{\mathrm{V}} / \mathrm{F}_{\mathrm{M}}$ in $1^{\text {st }} \mathrm{P} 0$, when the reduction was significantly lower. The same pattern of recovery of seedlings after the stress condition was suspended occurred regardless of the presence of hydrogel. However, in $2^{\text {nd }} \mathrm{P} 0$ the maintenance of $F_{V} / F_{M}$ stability in flooding situations can be highlighted, because the species $C$. odorata was adapted to these conditions, which contributed significantly to the seedlings, presenting higher values of photochemical activity regardless of the presence of the hydro-retainer polymer. This maintenance may probably be linked to the fact that the species are originated from humid, deep and well-drained environments and occur in soils of texture varying from clay to sand, and also flooded lands (Embrapa 2017).

The lower $\mathrm{F}_{\mathrm{V}} / \mathrm{F}_{\mathrm{M}}$ ratio in $1^{\text {st }} \mathrm{P} 0$ in seedlings with and without hydrogel caused collapses in the biochemical phase of photosynthesis, since $A / C_{\mathrm{i}}$ also decreased due to the inhibition of electron transport, which causes metabolic disturbances of active oxygen, and an increase of ethylene and other endogenous hormones (Liu et al. 2014).

These results are similar to those determined by Liang et al. (2019) for Populus nigra L., which showed a prominent decline in $\mathrm{F}_{\mathrm{V}} / \mathrm{F}_{\mathrm{M}}$ in water deficit conditions and by Junglos et al. (2018), for Ormosia arborea (Vell.) Harms, species tolerant to flooding, evaluated at 22 days of flooding. However, plants of Distylium chinense (Fr.) Diels submitted to flooding for 15 days showed a significant reduction in the values of $\mathrm{F}_{\mathrm{V}} / \mathrm{F}_{\mathrm{M}}$ indicating damage to the photochemical apparatus (Liu et al. 2014). Thus, the values verified for the ratio $\left(\mathrm{F}_{\mathrm{V}} / \mathrm{F}_{0}\right)$ confirm the damage to the photosynthetic device since this relationship has been used to amplify small variations in $\mathrm{F}_{\mathrm{V}} / \mathrm{F}_{\mathrm{M}}$ (Reis and Campostrini 2011). The values observed for $F_{V} / F_{0}$ in the $2^{\text {nd }} P 0$ (3.1) regardless of the presence of the $\mathrm{H}$, are lower than the range of 4 to 6 quantum per electrons pre-established for stress determination in most species, being slightly below the levels at which the functionality of reaction centers in photosystem II is preserved when facing water stress (Bento et al. 2016).

Lower yields of non-photochemical processes $\mathrm{F}_{0} / \mathrm{F}_{\mathrm{M}}$ in plants under water deficit are due to the instability of the use of light energy, which compromises electron transfer, regardless of the use of $\mathrm{H}$ (Fig. 2c). An increase in this characteristic in plants cultivated with and without $\mathrm{H}$, in the two phases of water fluctuations, was considered an indication of stress, because the values were higher than the range of 0.14 to 0.20 (Rohácek 2002; Rosa et al. 2018). This suggests stressful conditions. We emphasize that once more $\mathrm{H}$ did not significantly alter the recovery of $\mathrm{F}_{\mathrm{V}} / \mathrm{F}_{0}$ and $\mathrm{F}_{0} / \mathrm{F}_{\mathrm{M}}$ in both recovery times in $C$. odorata seedlings. Thus, we proved that water fluctuations cause weakness in the capacity to better use light and chemical energy in $C$. odorata seedlings, but that the damage is reversible once we observed the resumption of photochemical processes with the possibility of reaching values similar to that of control plants.

In addition, it is worth noting that the characteristics of chlorophyll $a$ fluorescence are important in the knowledge of the dynamics of photochemical processes in FS II and can contribute to the diagnosis of stress conditions for plants. For $\left(\mathrm{F}_{0} / \mathrm{F}_{\mathrm{M}}\right)$ the results are similar to those observed for other species considered tolerant to temporary water stress and with recovery potential after stress suspension. Thus, Reis et al. (2020) for Calophyllum brasiliense under water deficit and Rosa et al. (2018) for C. langsdorffii under flooding (during 42 days), observed similar results.

The reduction of the SPAD index in $C$. odorata seedlings under water stress shows the damage caused by the lack or excess of water on chlorophyll concentration, reducing the photosynthetic capacity of plants (Fig. 2d). A similar response was also observed in seedlings of Sacarum sp (Vieira et al. 2014) Jatropha curcas L. (Moura et al. 2016) and Hymenaea courbaril L. (Freitas et al. 2018).

The maintenance of this index in seedlings with $\mathrm{H}$ is possibly associated with a reduction in nutrient loss by leaching, providing a higher photosynthetic rate caused by nitrogen accumulation, directly linked to chlorophyll synthesis in plants; however, we did not evaluate this aspect. Our results corroborate those found by Felippe et al. (2016) where the chlorophyll content of Eucalyptus benthamii Maiden et Cambage plants was higher in treatments with the presence of this polymer.

The maintenance of a smaller leaf area in previously stressed seedlings, regardless of the presence of $\mathrm{H}$, proves that water fluctuations impaired the expansion (in area) 
under these cultivation conditions. The decrease in leaf area in seedlings under water stress is a favorable response and can reduce water loss by transpiration and loss of turgidity. So the metabolic and physiological processes of the plants are less impaired under these conditions. We emphasize that stress was more severe in $1^{\text {st }} \mathrm{P} 0$, because, among the morphological characteristics, the leaf area is the first characteristic impaired by water deficiency and represents an adaptive strategy for survival under stressful environment (Díaz-Lopez et al. 2012).

We emphasize the fact that $C$. odorata seedlings recover the characteristics of gas exchange, chlorophyll $a$ fluorescence, RWC and DQI after water fluctuations regardless of the presence of $\mathrm{H}$, which demonstrates physiological plasticity under adverse conditions. Because it is a species found throughout the Amazon and the Atlantic Forest region, it needs deep, most and well drained soils, with clayey texture (Quesada et al. 2011; Carrero et al. 2017). DQI represents the standard quality of seedlings, i.e., the distribution of dry mass and robustness in the plant. Thus, the species of these areas use different survival mechanisms to withstand stressful environment related to the lack of $\mathrm{O}_{2}$ and manage to survive during and after the stressful periods (Scremin-Dias et al. 2011).

In view of the results found in this research, we suggest that new studies should be carried out by testing different doses of the hydro-retainer polymer to achieve more efficient results of mitigation of water stress damages, and even find a longer period so that photosynthesis reach values close to zero, managing to anticipate adjustment responses to water stress (deficit and flooding) and be able to withstand longer periods of water deficit and flooding.

\section{Conclusion}

C. odorata is sensitive to water variations in the soil, but recovers photosynthetic metabolism and seedling quality once the water stress condition is suspended. The application of the hydro-retainer polymer mitigated some harmful effects of water stress, but the seedlings recovered regardless of their presence. We suggest that new studies should be carried out by testing different doses of the hydroretainer polymer to achieve more efficient results of mitigation of water stress damages.

\section{Acknowledgements}

Coordination for the Improvement of Higher Education Personnel (CAPES) is duly acknowledged.

\section{Author Contributions}

SPQS and DMD planned the experiments, JMS and JKVS participated in the analysis, CCS, MSS, DMD and SPQS interpreted the results, statistically analyzed, made illustrations, and made the write up.

\section{Conflicts of Interest}

The authors declare no conflict of interest

\section{Data Availability}

The data included in this paper will be made available on a reasonable request

\section{Ethics Approval}

Not applicable

\section{References}

Agaba H, LJB Orikiriza, JFO Esegu, J Obua, JD Kabasa, A Hüttermann (2010). Effects of hydrogel amendment to different soils on plant available water and survival of trees under drought conditions. Clean Soil Air Water 38:328-335

Agaba H, LJB Orikiriza, J Obua, JD Kabasa, M Worbes, A Hüttermann (2011). Hydrogel Amendment to Sandy Soil Reduces Irrigation Frequency and Improves the Biomass of Agrostis sgrostis stolonifera. Agric Sci 2:544-550

Azevedo TLF, A Bertonha, ACA Gonçalves (2002). Use of hydrogel in agriculture. Rev Prog Ciên Agroambient 1:23-51

Bai W, J Song, H Zhang (2013). Repeated water absorbency of superabsorbent polymers in agricultural field applications: a simulation study. Acta Agric Soil Plant Sci 63:433-441

Bento LF, SPQ Scalon, DM Dresch, ZV Pereira (2016). Potential for recovery of Campomanesia xanthocarpa Mart. ex O. berg seedlings from water deficit. Afr J Agric Res 11:2775-2785

Bianchi L, GH Germino, MA Silva (2016). Adaptação das plantas ao déficit hídrico. Acta Igua 5:15-32

Carrero GC, RS Pereira, MA Jacaúna, MJ Lima Junior (2017). Southern Amazon trees: A guide to species of economic and ecological interest. Manaus: IDESAM. Available at: http://idesam.org/publicacao/idesamguia-especies_2ed.pdf.htm (Accessed: 24 September 2020)

Díaz-Lopez L, V Gimeno, I Simón, V Martínez, WM Rodriguez-Ortega, F García-Sánchez (2012). Jatropha curcas seedlings show a water conservation strategy under drought conditions based on decreasing leaf growth and stomatal conductance. Agric Water Manage 105:48-56

Dickson A, AL Leaf, JF Hosner (1960). Quality appraisal of white spruce and white pine seedling stock in nurseries. For Chron 36:10-13

Embrapa (2017). Árvores na agricultura: espécies mais adequada para inserção em sistema produtivo. Brasília. Available at: http://www.embrapa.br/agrobiologia/arvores-naagricultura/especies.htm (Accessed: 24 September 2020)

Felippe D, MC Navrosky, JA Sampietro, T Friogotto, JA Albuquerque, CS Mota, MO Pereira (2016). Effect of hydrogel on the growth of Eucalyptus benthamii Maiden seedlings submitted to different irrigation. Floresta 46:215-225

Ferreira DF (2014). Sisvar: A guide for its bootstrap procedures in multiple comparisons. Ciên Agrotec 38:109-112

Ferreira EA, VA Silva, EA Silva, HRO Silveira (2014). Hydrogel efficiency and physiological responses of seedlings of citrus apyrenic cultivars under water deficit. Pes Agropec Trop 44:158-165

Freitas VMB, SPQ Scalon, DM Dresch, SS Bastos, APR Souza (2018). Influence of exogenous application of abscisic acid in gas exchanges of Hymenaea courbaril L. (Fabaceae) seedlings subjected to water deficit. Floresta 48:163-172

Junglos FS, MS Junglos, DM Dresch, LF Bento, EF Santiago, MM Rosilda, SPQ Scalon (2018). Morphophysiological responses of Ormosia arborea (Vell.) Harms (Fabaceae) seedlings under flooding and postflooding conditions. Aust J Bot 66:489-499

Kew (2015). Royal Botanic Garden. Cedrela odorata L. Available at: http://www.refloresta-bahia.org/br/amargosa/cedrela-olderata.htm (Accessed: 24 September 2020) 
Li X, JZ He, JM Hughes, YR Liu, YM Zheng (2014). Effects of super-absorbent polymers on a soil-wheat (Triticum aestivum L.) system in the field. Appl Soil Ecol 73:58-63

Liang G, J Bu, S Zhang, G Jing, G Zhang, X Liu (2019). Effects of drought stress on the photosynthetic physiological parameters of Populus $\times$ euramericana "Neva". J For Res 30:409-416

Liu Z, R Cheng, X Xiao, Q Guo, N Wang (2014). Effect of off-season flooding on growth, photosynthesis, carbohydrate partitioning, and nutrient uptake in Distylium chinense. PLoS One 9; Article e107636

Lorenzi H (2013). Brazilian Trees: Manual for Identification and Cultivation of Native Tree Plants in Brazil, $4^{\text {th }}$ edn. Nova Odessa, Sao Paulo, Brazil

Mielke MS, B Schaffer (2010a). Leaf gas exchange, chlorophyll fluorescence and pigment indexes of Eugenia uniflora L. in response to changes in light intensity and soil flooding. Tree Physiol 30:45-55

Mielke MS, B Schaffer (2010b). Photosynthetic and growth responses of Eugenia uniflora L. seedlings to soil flooding and light intensity. Environ Exp Bot 68:113-121

Miller G, N Suzuki, S Cifcit-Yilmaz, R Mittler (2010). Reactive oxygen species homeostasis and signaling during drought and salinity stresses. Plant Cell Environ 33:453-467

Moura AR, RJMC Nogueira, JAA Silva, TV Lima (2016). Water relations and organic solutes in young plants of Jatropha curcas L. under different water regimes. Cien Florestal 26:345-354

Navroski MC, MM Araújo, FS Cunha, ALP Berghetti, MO Pereira (2014). Influência do polímero hidroretentor na sobrevivência de mudas de Eucalyptus dunnii sob diferentes manejos hídricos. Rev Nativa 2:108-113

Navroski MC, MM Araújo, FS Cunha, ALP Berghetti, MO Pereira (2016). Reduction of manure and improvement of the characteristics of substrate using hydrogel in the seedling production of Eucalyptus dunnii Maiden. Ciênc Florest 26:1155-1165

Oliveira PS, LD Silva, TA Santana, BG Laviola, AQ Paiva, MS Mielke, FP Gomes (2016). Morphophysiological changes in young plants of Jatropha curcas L. (Euphorbiaceae) subjected to water stress and recovery. Afr J Agric Res 11:4692-4703

Parolin P, F Wittmann (2010). Struggle in the flood: tree responses to flooding stress in four tropical floodplain systems. AoB Plants 2010; Article plq003

Pereira WP, PA Melo Filho, MB Albuquerque, RJMC Nogueira, RC Santos (2012). Biochemical changes in peanut genotypes submitted to moderate water stress. Rev Ciên Agron 43:766-773
Quesada CA, J Lioyd, LO Anderson, NM Fyllas, M Schwarz, CI Czimczik (2011). Soils of Amazonia with particular reference to the RAINFOR sites. Biogeosciences 8:1415-1440

Reis FO, E Campostrini (2011). Water microaspersion upon tree canopy: A study relating to gas exchange and photochemical efficiency in papaya trees. Rev Bras Agro 17:66-77

Reis LC, SPQ Scalon, DM Dresch, A Foresti, Santos, ZV Pereira (2020). Chlorophyll a fluorescence as an indicator of water stress in Calophyllum brasiliense. Not Bot Hort Agrobot 48:210-220

Rohácek K (2002). Chlorophyll fluorescence parameters: The definitions, photosynthetic meaning, and mutual relationships. Photosynthetica 40:13-29

Rosa DBCJ, SPQ Scalon, T Cremon, DM Dresch (2018). Gas exchanges and antioxidant activity in Copaifera langsdorffii Desf. seedlings after flooding. Amer J Plant Sci 9:979-994

Scremin-Dias E, AP Lorenz-Lemke, AKM Oliveira (2011). The floristic heterogeneity of the Pantanal and the occurrence of species with different adaptive strategies to water stress. Braz J Biol 71:275-282

Slavick B (1979). Methods of Studying Plant Water Relations, Vol. 9. Springer-Verlag Berlin Heidelberg, Germany

Souza CC, FA Oliveira, IF Silva IF, MS Amorim Neto (2000). Recovery of methods for determining available water and irrigation management on purple soil under herbaceous cotton cultivation. Rev Bras Eng Agr Amb 4:338-342

Taiz L, E Zeiger, I Moller, A Murphy (2017). Plant Physiology and Development, $6^{\text {th }}$ edn. Snaur Associates Inc., Sunderland, Massachusetts, USA

Vieira GHS, EC Mantovani, GC Sediyama, FT Delazari (2014). Morphophysiological indicators of water stress for the cultivation of sugarcane as a function of irrigation depths. Biosci J 30:65-75

Vieira SB, JOP Carvalho, JM Gomes, CF Silva, AR Ruschel (2018). Cedrela odorata $\mathrm{L}$. has the potential to be used in post-harvest silviculture in the Brazilian Amazon? Ciênc Flor 28:1230-1238

Vítolo HF, GM Souza, JAG Silveira (2012). Cross-scale multivariate analysis of physiological responses to high temperature in two tropical crops with C3 and C4 metabolism. Environ Exp Bot 80:54 62

Xu S, L Zhang, NB McLaughlin, J Mi, Q Chen, J Liu (2015). Effect of synthetic and natural water absorbing soil amendment soil physical properties under potato production in a semi-arid region. Soil Till Res 148:31-39 